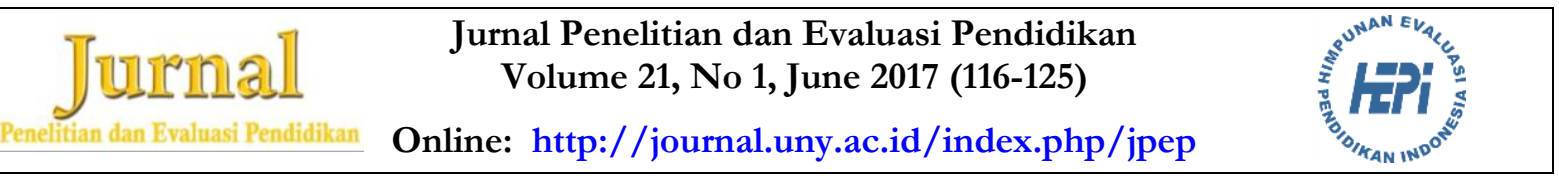

\title{
PENGEMBANGAN TES KETERAMPILAN DASAR OLAHRAGA BOLA TANGAN BAGI MAHASISWA
}

\author{
Ermawan Susanto \\ Fakultas Ilmu Keolahragaan Universitas Negeri Yogyakarta \\ Jl. Colombo No. 1, Depok, Sleman 55281, Yogyakarta, Indonesia \\ Email: ermawan_s@yahoo.com
}

\begin{abstract}
Abstrak
Artikel ini bertujuan untuk: (1) menyusun butir-butir tes keterampilan dasar olahraga bola tangan, dan (2) mengetahui validitas dan mengestimasi reliabilitas tes keterampilan dasar olahraga bola tangan. Metode penelitian yang digunakan adalah research and development. Subjek penelitian 30 mahasiswa. Instrumen pengumpulan data berupa lembar observasi dan kuesioner. Jumlah judge yang terlibat 3 orang. Validitas diketahui dengan validitas isi dan reliabilitas instrumen menggunakan korelasi Inter Rater. Hasil penghitungan koefisien korelasi, diketahui bahwa skor rater $1=0,999$, skor rater $2=0,996$, dan skor rater $3=0,991$. Hasil penghitungan reliabilitas diestimasi dengan Koefisien Alpha sebesar $r_{\mathrm{xx}}=\mathbf{0 , 9 9 4}$. Hasil pengembangan tes keterampilan dasar olahraga bola tangan bagi mahasiswa menghasilkan 3 (tiga) jenis tes yaitu: (1) Tes keterampilan passing dengan sasaran ke tembok (waktu: 30 detik), (2) Tes keterampilan dribbling (waktu: 30 detik), (3) Tes keterampilan flying shoot melakukan 3 kali tembakan dari tiga posisi: kiri, tengah, dan kanan.
\end{abstract}

Kata kunci: pengembangan tes, keterampilan dasar, bola tangan

\section{DEVELOPMENT OF HANDBALL BASIC SKILLS TEST FOR STUDENTS}

\begin{abstract}
This article aims to: (1) develop a grain handball basic skills test, and (2) determine the validity and reliability of estimating handball basic skills test. The method used is research and development. Subject of the study 30 students. Data collection such as observation sheets and questionnaires. Number judge involved three people. Validity determined by content validity and reliability of the instrument using the correlation Inter Rater. The results of the correlation coefficient calculation, it is known that the rater score $1=0.999$, the rater score $2=0.996$, and the score rater $3=0.991$. The results estimated by the reliability calculation of Alpha Coefficient $r_{x x}=\mathbf{0 , 9 9 4}$. The result of the development of the form of handball basic skills test for students produce three (3) types of test are: (1) The test of passing skills the target wall (time: 30 seconds), (2) the tests of dribbling skills (time: 30 seconds) (3) The tests of flying shoot skills from three positions: left, center, and right.
\end{abstract}

Keywords: test, development, handball basic skill

Permalink/DOI: http:/ / dx.doi.org/10.21831/pep.v21i1.15784 



\section{Pendahuluan}

Olahraga permainan bola tangan (Sport Handball) merupakan cabang olahraga yang sebenarnya telah lama dikenal di Indonesia, dan sampai saat ini masih menjadi salah satu matakuliah yang diajarkan di Lembaga Pendidikan Tinggi Kependidikan (LPTK) keolahragaan. Keberadaannya kurang diperhitungkan karena beberapa hal, jenis permainan yang kurang populer, minim sosialisasi, dan tidak memiliki induk organisasi olahraga yang resmi. Sebagai salah satu cabang olahraga permainan, bola tangan memiliki beberapa dampak positif bagi pelakunya antara lain perkembangan fisik, kedisipinan, kerja sama, sosial emosional, dan keterampilan hidup. Hal ini tentu sesuai dengan tujuan pendidikan nasional secara umum. Demikian pula olahraga bola tangan dapat ditelusuri kebenaran sejarahnya dan telah berusia sangat tua. Sebuah fakta yang meyakinkan telah menunjukkan seseorang memainkan bola tangan jauh lebih awal daripada sepak bola. Permainan bolatangan yang dimainkan pada masa Yunani kuno merupakan sebuah isyarat terciptanya olahraga bola tangan modern (IHF, 2012, p.5).

Pada sejarahnya tahun 1928 International Amateur Handball Federation (IAHF) telah dideklarasikan bertepatan dengan Olimpiade Amsterdam dengan ketua Avery Brundage dari USA. Setelah tahun 1936 negara anggota IAHF menjadi 23 negara dan dilanjutkan dengan sebuah kompetisi yang disebut dengan "Berlin Olympic Games" di kota Berlin, Jerman. Tahun 1938 untuk pertama kali diselenggarakan Kejuaraan Dunia Bolatangan juga di Jerman. Akhirnya pada tahun 1946 atas usulan dan undangan Denmark dan Swedia, delapan negara memprakarsai Federasi Bola tangan Internasional. Delapan negara tersebut adalah; Denmark, Finlandia, Perancis, Belanda, Norwegia, Polandia, Swedia, dan Swiss (Moustafa, 2010, p.48-50).

Olahraga bola tangan dikatakan sebagai olahraga cepat dan dinamis yang dimainkan di dalam ruangan (indoor). Dalam catatan sejarah, olahraga ini telah dimainkan di lebih dari 150 negara. Bahkan sampai de- ngan tahun 2003, IHF memiliki jumlah anggota 150 negara dengan jumlah klub sebanyak 80.000 dan 19 juta atlit putra maupun putri (Rachman \& Susanto, 2005, p.12).

Dalam permainannya bola tangan dimainkan di atas lapangan dengan panjang 40 meter x 20 meter. Saat berlangsung permainan, masing-masing tim terdiri atas 6 pemain dan 1 penjaga gawang. Waktu yang digunakan adalah $2 \times 30$ menit. Setiap tim terdiri dari 12 pemain. Namun, hanya 7 pemain yang ada di lapangan termasuk dengan seorang penjaga gawang. Selebihnya adalah pemain pengganti selama permainan.

Permainan bola tangan terdiri atas beberapa teknik dasar seperti warming-up, dribbling, passing, shooting, possitioning, attacking exercise, defencing exercise, dan fast break exercise namun dalam permainan hanya tiga teknik dasar yang paling sering digunakan, diantaranya; (1) teknik dribbling yaitu upaya pemain untuk membawa bola mendekati daerah pertahanan lawan dengan cara memantulkan bola ke lantai, (2) teknik passing yaitu upaya memberikan bola kepada teman dengan menggunakan satu atau dua tangan, (3) teknik shooting atau menembak bola ke gawang.

Menggiring (dribble) adalah keterampilan untuk menguasai dan membawa bola dengan cara memantulkannya setiap kali ke tanah, dengan satu atau dua tangan. Menggiring bola merupakan keterampilan yang cukup sulit karena memerlukan koordinasi mata dan tangan yang tinggi. Perlu diingat bahwa arah pantulan bola akan tergantung pada arah datang dari bola itu ke tanah. Cepat atau lambatnya pergerakan bola berasal dari kuat lemahnya menggiring bola tersebut.

Melempar atau passing adalah pola gerak dasar yang dimaksudkan untuk melepaskan suatu objek menjauhi tubuh pelempar. Gaya melempar memang berbeda-beda sesuai keperluannya tetapi pola dasarnya tetap konsisten atau sama. Bola dilempar kemudian bola tersebut harus ditangkap. Posisi tubuh untuk menangkap harus memungkinkan. Menembak (shooting) merupakan salah satu teknik terpenting dalam permainan bola tangan karena dengan teknik shooting kemungkinan terciptanya gol sangat besar. 
Beberapa teknik shooting yang ada ialah flying shoot, drive shoot, jump shoot, dan straight shoot. Setiap regu berusaha dengan sekuat tenaga untuk memasukkan bola ke gawang agar kemenangan dapat diraih.

Namun demikian dalam perkuliahan dasar gerak bola tangan di jurusan pendidikan olahraga FIK UNY, belum ada instrumen tes keterampilan bola tangan bagi mahasiswa. Padahal instrumen tes keterampilan disusun guna mendukung pelaksanaan perkuliahan dan untuk mengukur keterampilan mahasiswa. Instrumen keterampilan dasar bolatangan yang akan disusun meliputi tes keterampilan melempar bola (passing), tes menggiring bola (dribbling), dan tes menembak bola (shooting).

Matakuliah dasar gerak bola tangan (Foundation of Handball Tecbnique) merupakan matakuliah yang bersifat fakultatif dan diajarkan kepada seluruh program studi yang ada di Fakultas Ilmu Keolahragaan UNY. Matakuliah ini berbobot 1 sks dengan pelaksanaan praktek di lapangan. Matakuliah ini mengenalkan teknik dasar menggiring bola (dribbling), lemparan (passing), tembakan melayang bolatangan (flying shoot), peraturan permainan bola tangan, dan praktik bermain bola tangan (Kurikulum FIK, 2014, p. 42). Bola tangan merupakan cabang olahraga yang sebenarnya telah lama dikenal dan menjadi salah satu matakuliah yang diajarkan di LPTK keolahragaan.

Bola tangan (handball) diartikan sebagai permainan beregu yang menggunakan bola sebagai alatnya dan dimainkan dengan menggunakan satu atau kedua tangan. Bola tersebut dapat dilempar, dipantulkan, atau ditembakkan. Induk organisasi dari bola tangan ini adalah International Handball Federation (IHF) dan di Indonesia sendiri adalah Asosiasi Bola Tangan Indonesia (ABTI). Tujuan dari permainan ini adalah memasukkan bola sebanyak-banyaknya ke gawang lawan, dan mencegah agar tim lawan tidak dapat memasukkan bola ke gawang kita sendiri. Kunci keberhasilan agar dapat bermain dengan baik, seseorang harus mengerti dan benar-benar dapat menguasai teknik-teknik dasar yang ada seperti passing, dribble, dan shooting. Melempar atau passing adalah pola gerak dasar yang dimaksudkan untuk melepaskan suatu objek menjauhi tubuh pelempar. Gaya melempar memang berbeda-beda sesuai keperluannya tetapi pola dasarnya tetap konsisten atau sama. Bola dilempar kemudian bola tersebut harus ditangkap.

Penilaian suatu keterampilan dapat dilakukan dengan berbagai cara, salah satunya melalui pengamatan. Pengamatan dilakukan untuk mengetahui perkembangan dan sikap anak dalam kehidupan sehari-hari secara terus menerus (Depdiknas, 2003, p. 12). Berbagai alat penilaian yang dapat digunakan untuk memperoleh gambaran perkembangan perilaku anak, antara lain: (1) Portofolio yaitu penilaian berdasarkan kumpulan hasil kerja. (2) Unjuk kerja (performance) merupakan penilaian yang menuntut tugas dalam perbuatan yang dapat diamati, misalnya praktek olahraga, (3) Penugasan (Project) merupakan tugas yang memerlukan waktu relatif lama dalam pengerjaannya. (4) Hasil karya (Product) merupakan hasil kerja anak setelah melakukan suatu kegiatan.

Instrumen adalah suatu alat yang memenuhi persyaratan akademis sebagai alat untuk mengukur suatu objek ukur atau mengumpulkan data mengenai suatu variabel. Instrumen tersebut dapat digunakan untuk mengumpulkan data penelitian. Instrumen dibagi menjadi dua macam, yakni tes dan non-tes. Instrumen kelompok tes, misalnya tes prestasi belajar, tes inteligensi, tes bakat, tes keterampilan; sedangkan non-tes misalnya pedoman wawancara, angket atau kuesioner, pedoman observasi, daftar cocok (check list), dan skala penilaian (Sukmadinata, 2004, p. 47). Keterampilan gerak dasar bola tangan diukur menggunakan tes. Tes sebagai instrumen pengumpulan data adalah serangkaian latihan yang digunakan untuk mengukur keterampilan, pengetahuan, intelegensi, kemampuan atau motorik (Sugiyono, 2003, p. 138).

Terdapat empat konsep mendasar dalam menyusun tes yaitu validitas, reliabilitas, objektivitas dan norma. Valid berarti instrumen dapat digunakan untuk mengukur apa saja yang seharusnya diukur, reliabel berarti 
instrumen yang bila digunakan beberapa kali untuk mengukur objek yang sama, akan menghasilkan data yang sama. Reliabilitas instrumen keterampilan gerak bola tangan diestimasi dengan cara melakukan uji coba instrumen beberapa kali kepada responden, apabila koefisien korelasi positif dan signifikan maka instrumen dinyatakan reliabel. Instrumen keterampilan dasar bola tangan, disusun sendiri oleh peneliti danterdiri atas (1) ketepatan isi materi instrumen, (2) kelengkapan isi materi instrumen, (3) keterlaksanaan instrumen.

\section{Metode Penelitian}

Desain atau rancangan penelitian ini berbentuk penelitian pengembangan instrumen tes keterampilan research \& development (Borg \& Gall, 1983, p. 774) yang bertujuan sebagai alat ukur keberhasilan keterampilan bola tangan pada mahasiswa. Instrumen penelitian disusun sendiri oleh peneliti terdiri atas (1) ketepatan isi materi instrumen, (2) kelengkapan isi materi instrumen, (3) keterlaksanaan instrumen.

Penelitian dilakukan pada matakuliah olahraga pilihan permainan bola tangan prodi PJKR yang dilaksanakan pada semester enam (genap) di GOR Fakultas Ilmu Keolahragaan Universitas Negeri Yogyakarta. Subjek penelitian adalah mahasiswa prodi PJKR yang mengambil matakuliah sejumlah 30 mahasiswa. Instrumen pengumpulan data menggunakan pedoman observasi. Observasi digunakan untuk mendapatkan atau menjaring informasi dari para ahli sebagai expert judgement untuk memberikan masukan dan saran tentang instrumen tes keterampilan yang akan dihasilkan. Jumlah judge yang terlibat sejumlah 2 orang ahli pembelajaran bola tangan. Sebelum digunakan untuk pengambilan data yang asli kepada mahasiswa, dilakukan uji coba instrumen untuk mengetahui validitas serta reliabilitasnya. Validitas dan reliabilitas instrumen dibuktikan dengan uji korelasi Inter Rater. Analisa data menggunakan Anova-General Multifacet Model (Thorndike, 1982, p. 161).

Validitas dilakukan melalui analisis faktor terhadap instrumen dengan cara meng- korelasikan jumlah skor item pengamatan dengan skor total. Reliabilitas menggunakan nilai korelasi ICC atau dapat juga dihitung dengan rumus manual berdasar tabel ANOVA.

Secara garis besar langkah-langkah penyusunan dan pengembangan instrumen (Hadi, 2004, pp. 22-24), adalah sebagai berikut.

1. Berdasarkan sintesis dari teori-teori yang dikaji tentang suatu konsep dari variabel yang hendak diukur, maka dirumuskan konstruk dari variabel tersebut. Konstruk dalam penelitian ini adalah tes keterampilan dasar olahraga bola tangan.

2. Menetapkan besaran atau parameter. Pada penelitian ini besaran atau parameter keberhasilan keterampilan dasar olahraga bola tangan adalah tes passing, tes dribbling, dan tes shooting.

3. Jenis tes keterampilan yang akan dibuat harus melalui proses validasi, baik validasi teoretik maupun validasi empirik.

4. Revisi berdasarkan saran dari pakar atau berdasarkan hasil judgements.

5. Setelah konsep tes dianggap valid secara teoretik atau secara konseptual, dilakukanlah penggandaan tes secara terbatas untuk keperluan ujicoba.

6. Uji coba tes keterampilan dasar olahraga bola tangan di lapangan merupakan bagian dari proses validasi empirik. Melalui ujicoba tersebut, tes diberikan kepada sejumlah responden yaitu mahasiswa sebagai sampel uji coba, untuk kemudian diketahui valid atau tidaknya sebuah perangkat tes.

7. Selanjutnya dihitung koefisien reliabilitas. Koefisien reliabilitas dengan rentangan nilai (0-1) adalah besaran yang menunjukkan kualitas atau konsistensi hasil ukur tes. Makin tinggi koefisien reliabilitas makin tinggi pula kualitas tes.

8. Apabila ketujuh tahapan tersebut selesai kemudian tes jadi.

Penghitungan validitas dilakukan melalui analisis faktor terhadap instrumen dengan cara mengkorelasikan jumlah skor item

Pengembangan Tes Keterampilan Dasar Olahraga ... - 119 Ermawan Susanto 
pengamatan dengan skor total. Uji korelasi dilakukan untuk mencari besarnya hubungan dan arah hubungan. Nilai korelasi berkisar dalam rentang 0 sampai 1 atau 0 sampai -1 (Trihendardi, 2004, p.146)

Nilai korelasi ICC dapat juga dihitung dengan rumus manual berdasar tabel ANOVA seperti di bawah ini:

$$
r=\frac{M S_{\text {people }}-M S_{\text {residual }}}{M S_{\text {people }}-\left(d f_{\text {people }} \times M S_{\text {residual }}\right)}
$$

Hubungan antara ICC dengan alpha dapat diketahui melalui rumus berikut:

$$
\alpha=\frac{k \times r}{1+(k-1) \times r}
$$

Besarnya nilai koefisien korelasi (r) dikategorikan sebagai berikut:

1. $0.7-1.00$ baik positif maupun negatif, menunjukkan derajat hubungan yang tinggi,

2. $0.4-0.7$ baik positif maupun negatif, menunjukkan derajat hubungan substansial,

3. $0.2-0.4$ baik positif maupun negatif, menunjukkan derajat hubungan yang rendah,

4. < 0.2 baik positif maupun negatif, hubungan dapat diabaikan (Trihendardi, 2006, p. 145)

Penelitian ini bersifat uji coba pengembangan tes keterampilan gerak atau motorik fisik, teknik analisis data yang digunakan adalah dengan menilai tingkat kelayakan, kualitas, dan ketepatan tes yang dihasilkan. Tes dikatakan layak/tepat apabila langkah-langkah penelitian dapat dilaksanakan di setiap uji coba dan semua unsur yang terlibat. Selanjutnya tes dikatakan layak/ tepat, apabila dapat dipakai untuk mengukur keterampilan dasar olahraga bola tangan pada mahasiswa.

\section{Hasil Penelitian dan Pembahasan}

Data Analisis Kebutuhan

Analisis kebutuhan dalam penyusunan tes diperlukan untuk menyusun dan menggali permasalahan tes keterampilan dasar bola tangan bagi mahasiswa. Kegiatan ini dilakukan dengan cara menganalisis proses perkuliahan di lapangan, melakukan observasi, dan melakukan studi pustaka/ kajian literatur. Produk yang dihasilkan antara lain: (1) draft tes keterampilan dasar bola tangan bagi mahasiswa, (2) validitas dan reliabilitas tes keterampilan dasar bola tangan bagi mahasiswa, (3) butir-butir tes keterampilan dasar bola tangan bagi mahasiswa yang valid untuk diseminasikan menjadi instrumen final.

\section{Validasi Ahli Draft Tes Keterampilan}

Produk awal tes keterampilan dasar bola tangan sebelum diujicobakan dalam uji kelompok kecil dilakukan validasi oleh para ahli yang sesuai dengan bidang penelitian. Untuk memvalidasi produk yang akan dihasilkan, melibatkan dua (2) orang ahli keterampilan bola tangan sekaligus menguasai bidang pendidikan jasmani yang berasal dari dosen. Validasi dilakukan dengan cara memberikan draft produk awal, dengan disertai lembar evaluasi ahli.

Hasil evaluasi berupa nilai untuk aspek kualitas menggunakan skala likert 1 sampai 4. Data yang diperoleh dari pengisian kuesioner oleh para ahli, merupakan pedoman untuk menyatakan apakah produk tes keterampilan dasar bola tangan dapat digunakan untuk uji coba skala kecil dan skala luas. Berikut ini adalah draft tes keterampilan dasar bola tangan:

\section{Tes Keterampilan Passing (waktu: 30 detik)}

Tujuan : Untuk mengukur kemampuan melempar dan menangkap bola secara terus menerus.

Alat yang digunakan:
a. Bola tangan, 2 buah
b. Dinding/tembok
c. Stop watch
d. Pita pengukur
e. Kapur/ lakban

Tes Keterampilan Dribbling (jarak: 40 m)

Tujuan : untuk mengukur kemampuan menggiring bola di lapangan. 
Alat yang digunakan:
a. Bola
b. Stop watch
c. Pita pengukur
d. Kapur/ lakban

Tes Keterampilan Flying Shoot (melakukan 6 kali tembakan)

Tujuan : untuk mengukur keterampilan menembak secara berturut-turut dari tiga posisi.

Alat yang digunakan:
a. Gawang

b. Tali
c. Pita pengukur
d. Bola, 6 buah

Berdasarkan hasil pengisisan kuesioner yang dilakukan oleh masing-masing ahli didapat rata-rata lebih dari 3 (tiga) atau masuk dalam kategori penilaian "baik/tepat/jelas". Oleh karena itu dapat disimpulkan bahwa instrumen tes keterampilan dasar bola tangan dapat digunakan untuk uji coba skala kecil. Masukan yang berupa saran dan komentar pada produk, sangat diperlukan untuk perbaikan pada tahap berikutnya.

Tabel 1. Hasil Pengisian Kuesioner Ahli

\begin{tabular}{|c|c|c|c|}
\hline No & Aspek yang Dinilai & $\begin{array}{l}\text { Nilai Ahli } \\
\text { A1 }\end{array}$ & $\begin{array}{c}\text { Nilai Ahli } \\
\text { A2 }\end{array}$ \\
\hline 1. & $\begin{array}{l}\text { Kesesuaian dengan kompetensi } \\
\text { perkuliahan }\end{array}$ & 4 & 4 \\
\hline 2. & $\begin{array}{l}\text { Kesesuaian dengan materi dasar bola } \\
\text { tangan }\end{array}$ & 3 & 3 \\
\hline 3. & $\begin{array}{l}\text { Ketepatan tes keterampilan dasar bola } \\
\text { tangan. }\end{array}$ & 2 & 3 \\
\hline 4. & Kesesuaian alat dan fasilitas. & 3 & 4 \\
\hline 5. & $\begin{array}{l}\text { Kemudahan tes keterampilan untuk } \\
\text { dilakukan. }\end{array}$ & 3 & 3 \\
\hline 6. & $\begin{array}{l}\text { Kesesuaian tes keterampilan dengan usia } \\
\text { mahasiswa. }\end{array}$ & 4 & 4 \\
\hline 7. & Mendorong perkembangan aspek fisik . & 3 & 4 \\
\hline 8. & Mendorong perkembangan aspek kognitif. & 3 & 4 \\
\hline 9. & $\begin{array}{l}\text { Mendorong perkembangan aspek } \\
\text { psikomotor. }\end{array}$ & 4 & 4 \\
\hline 10. & Mendorong perkembangan aspek afektif. & 2 & 3 \\
\hline 11. & Dapat dilakukan siswa putra maupun putri. & 4 & 4 \\
\hline 12. & Mampu mengukur keterampilan dasar. & 3 & 4 \\
\hline 13. & $\begin{array}{l}\text { Meningkatkan minat dan motivasi } \\
\text { mahasiswa. }\end{array}$ & 3 & 4 \\
\hline 14. & Aman untuk diterapkan dalam perkuliahan. & 3 & 4 \\
\hline \multicolumn{2}{|c|}{ Jumlah Skor } & 44 & 52 \\
\hline \multicolumn{2}{|c|}{ Rata-rata } & 3,14 & 3,71 \\
\hline
\end{tabular}

A1 $=$ Ahli 1

A2 $=$ Ahli 2 


\section{Uji Coba Skala Kecil}

Setelah produk tes keterampilan dasar bola tangan divalidasi oleh para ahli serta dilakukan revisi, kemudian produk diujicobakan kepada mahasiswa. Uji coba ini dilakukan terhadap 30 mahasiswa.

Uji coba bertujuan untuk mengetahui dan mengidentifikasi berbagai permasalahan seperti kelemahan, kekurangan, ataupun keefektifan tes keterampilan. Pengamatan yang dilakukan oleh rater, merupakan salah satu indikator untuk mengetahui keefektifan tes. Pengamatan oleh rater dilakukan selama tes berlangsung. Berdasarkan hasil pengamatan, didapatkan tiga bentuk tes keterampilan bola tangan dan nilai validitas instrumen.

\section{Validitas Tes}

Jumlah subjek atau mahasiswa yang digunakan dalam uji coba skala kecil adalah sejumlah 30 mahasiswa. Uji korelasi dilakukan dengan uji inter rater (antar penilai), analisa data menggunakan Anova-General Multifacet Model dari Thorndike yaitu untuk menguji dua variabel bertipe ordinal dan skala dengan distribusi normal/parametrik. Data hasil uji validitas pengamatan menunjukkan derajat hubungan yang tinggi sebesar rata-rata $\mathbf{0 . 9 9 5}$.

Tabel 2. Tingkat Validitas Tes Bola Tangan

\begin{tabular}{cccc}
\hline No & $\begin{array}{c}\text { Perbandingan } \\
\text { skor }\end{array}$ & Koef. kor & Status \\
\hline 1 & $\begin{array}{l}\text { Rater } 1-\text { skor } \\
\text { total rater }\end{array}$ & $\mathrm{r}=0.999$ & Valid \\
2 & $\begin{array}{l}\text { Rater } 2-\text { skor } \\
\text { total rater }\end{array}$ & $\mathrm{r}=0.996$ & Valid \\
3 & $\begin{array}{l}\text { Rater } 3-\text { skor } \\
\text { total rater }\end{array}$ & $\mathrm{r}=0.991$ & Valid \\
\hline
\end{tabular}

Dengan demikian berdasarkan penghitungan statistik validitas uji coba tes keterampilan, diketahui terdapat tingkat hubungan positif yang tinggi, sehingga instrumen dinyatakan valid dan dapat digunakan untuk pengambilan data pada skala luas. Berdasarkan hasil analisis faktor tersebut dapat disimpulkan bahwa tes tersebut memiliki construct validity yang baik, artinya tes tersebut dapat digunakan untuk mengukur gejala sesuai dengan yang didefinisikan (Sugiyono, 2003, p. 170).

\section{Reliabilitas Tes}

Uji reliabilitas antar rater terdiri dari dua jenis, uji koefisien korelasi Kesepakatan Antar Rater dari Kappa dan uji koefisien korelasi Antar-Kelas (Intraclass Correlation Coefficients, ICC). Uji reliabilitas antar rater dari Kappa digunakan apabila rater berjumlah dua orang sedangkan uji reliabilitas antar rater ICC digunakan apabila rater lebih dari 2 orang (Widhiarso, 2006, p.15). Penelitian ini menggunakan 3 rater sehingga menggunakan koefisien korelasi Antar Kelas. ICC menunjukkan perbandingan antara variasi yang diakibatkan atribut yang diukur dengan variasi pengukuran secara keseluruhan. Berdasarkan penghitungan statistik reliabilitas uji coba skala kecil, diketahui terdapat nilai reliabilitas Antar-Rater yang tinggi yaitu 0.994, sehingga instrumen dinyatakan reliabel dan dapat digunakan untuk pengambilan data.

\section{Pembahasan}

Berdasarkan hasil distribusi frekuensi pada 30 mahasiswa, diketahui: (1) menurut rater 1 yang termasuk dalam kategori baik berjumlah 22 mahasiswa (74\%), kategori sedang berjumlah 6 mahasiswa (20\%), dan kategori kurang berjumlah 2 mahasiswa $(6 \%)$, (2) menurut rater 2 yang termasuk dalam kategori baik berjumlah 20 mahasiswa (68\%), kategori sedang berjumlah 8 mahasiswa $(26 \%)$, dan kategori kurang berjumlah 2 mahasiswa (6\%), (3) menurut rater 3 yang termasuk dalam kategori baik berjumlah 20 mahasiswa (68\%), kategori sedang berjumlah 8 mahasiswa (26\%), dan kategori kurang berjumlah 2 mahasiswa (6\%). Rata-rata distribusi frekuensi psikomotorik pada $30 \mathrm{ma}-$ hasiswa, diketahui bahwa: (1) yang termasuk kategori baik berjumlah 21 mahasiswa (70\%), (2) yang termasuk kategori sedang berjumlah 7 mahasiswa (23\%), (3) yang termasuk kategori kurang berjumlah 2 mahasiswa $(7 \%)$. 
Berdasarkan langkah-langkah penelitian pengembangan untuk menghasilkan produk yang telah dilakukan, maka didapatkan produk akhir berupa tes keterampilan dasar olahraga bola tangan. Indikator keberhasilan produk ini ialah adanya kesamaan persepsi antar rater berupa lembar penilaian hasil pengamatan terhadap seluruh subjek yang diujicobakan dalam penelitian. Berdasarkan uji coba yang dilakukan pada 30 mahasiswa yang memiliki karakteristik sama, didapatkan hasil yang hampir sama, artinya produk yang diujicobakan bisa diterapkan pada kelompok mahasiswa dengan karakteristik yang sama.

Secara permainan, olahraga bola tangan akan berjalan dengan benar apabila pemain mampu menguasai keterampilan dasar bola tangan. Keterampilan dasar yang dimaksud antara lain : (1) Ball bandling, (2) Dribbling, (3) Passing, (4) Shooting, dan (5) Positioning (Thum, 2005, pp. 45-47). Dribbling adalah keterampilan menggiring bola yang bertujuan melakukan penyerangan dengan menggiring bola kemudian mendekatkannya pada area tembakan. Driblling dalam permainan bola tangan dikenal dengan teknik "tiga langkah sekali pantul." Menggiring bola merupakan suatu pergerakan memantulkan bola ke lantai secara kontinyu dengan menggunakan sebelah tangan atau bertukar tangan tanpa memegang bola. Keterampilan menggiring digunakan dalam 3 situasi; (1) Bergerak bebas bila tidak ada penjagaan lawan; (2) Satu lawan satu; (3) Pemain lawan tidak dapat membuat halangan setelah menerima bola.

Passing atau melempar bola adalah keterampilan memberikan bola kepada kawan dalam permainan. Tujuan passing adalah untuk memberikan bola kepada kawan yang kemudian melakukan shooting, atau untuk tujuan strategi penyerangan maupun pertahanan. Terdapat berbagai macam keterampilan passing dalam permainan bola tangan.

Shooting atau menembak adalah keterampilan melakukan tembakan sebagai bagian usaha untuk mencetak goal dalam permainan bola tangan. Tujuan shooting adalah untuk mencetak goal sebanyak-sebanyaknya ke gawang lawan. Terdapat berbagai macam keterampilan shooting dalam permainan bola tangan.

Dalam menyusun tes perlu diperhatikan empat konsep mendasar yang ada yaitu Validitas, Reliabilitas, Objektivitas dan Norma. Valid berarti tes dapat digunakan untuk mengukur apa saja yang seharusnya diukur, reliabel berarti tes yang bila digunakan beberapa kali untuk mengukur objek yang sama, akan menghasilkan data yang sama (Sugiyono, 2003, p.140). Pada pengukuran keterampilan dasar bola tangan mahasiswa maka menggunakan validitas konstruk (construct validity) dan validitas isi (content validity). Instrumen yang mempunyai validitas isi adalah instrumen yang berbentuk tes dan sering digunakan untuk mengukur prestasi belajar. Untuk menyusun tes keterampilan dasar bola tangan, maka disusun berdasarkan tiga komponen dasar: melempar bola (passing), menggiring bola (dribbling), dan menembak dengan bola (shooting). Adapun untuk menguji validitas konstruk menggunakan pendapat ahli (expert judgement). Untuk menguji reliabilitas instrumen keterampilan dasar bola tangan, dilakukan dengan cara melakukan uji coba tes beberapa kali kepada responden/model.

Tes sebagai instrumen pengumpulan data adalah serangkaian latihan yang digunakan untuk mengukur keterampilan pengetahuan, intelegensi, motorik yang dimiliki oleh individu atau kelompok. Ada beberapa alasan mengapa tes perlu dilakukan yaitu: (1) mengklasifikasikan peserta didik, (2) mendiagnosa kebutuhan dan kelemahan peserta didik, (3) evaluasi pembelajaran, (4) evaluasi program, (5) marking/griding, (6) motivasi, (7) alat pembelajaran, (8) prediktor penelitian (Suntoda, 2007, p. 67)

Tes keterampilan dasar olahraga bola tangan merupakan bagian yang integral dalam proses penilaian hasil belajar mengajar dan latihan, melalui tes dan pengukuran kita akan memperoleh data yang objektif (Susanto, 2015, p. 75). Berdasarkan hasil pengembangan tes keterampilan dasar bola tangan bagi mahasiswa, diperoleh hasil tes sebagai berikut : 
1. Tes keterampilan passing dengan sasaran ke tembok (waktu: 30 detik)

2. Tes keterampilan dribbling (waktu: 30 detik)

3. Tes keterampilan flying shot melakukan 3 kali tembakan dari tiga posisi: kiri, tengah, dan kanan

Berikut ini adalah produk jadi berupa tes keterampilan dasar olahraga bola tangan bagi mahasiswa antara lain:

1. Tes keterampilan passing ( waktu: 30 detik)

Tujuan : mengukur kemampuan melempar dan menangkap bola secara terus menerus.

2. Tes keterampilan dribbling (jarak: $40 \mathrm{~m}$ ) Tujuan : Untuk mengukur kemampuan menggiring bola di lapangan.

3. Tes keterampilan flying shoot (melakukan 6 kali tembakan dari 3 posisi)

Tujuan : mengukur keterampilan menembak secara berturut-turut dari tiga posisi.

Untuk melakukan penilaian gerak, penting memperhitungkan prinsip-prinsip tes keterampilan. Prinsip tes tersebut salah satunya adalah fungsi pengembangan keterampilan motorik. Penilaian dalam bidang olahraga ada yang bersifat objektif dan ada yang subjektif. Dalam penilaian objektif tentunya berdasarkan hasil pengukuran yang objektif. Pada penilaian yang bersifat subjektif umumnya dilakukan terhadap performance.

\section{Simpulan}

Berdasarkan hasil penelitian pengembangan dan pembahasan di atas maka hasil penelitian menunjukkan telah tersusunnya 3 (tiga) jenis tes keterampilan dasar olahraga bola tangan bagi mahasiswa. Tes tersebut antara lain: (1) Tes keterampilan passing dengan sasaran ke tembok (waktu: 30 detik), (2) Tes keterampilan dribbling (waktu: 30 detik), (3) Tes keterampilan flying shoot melakukan 3 kali tembakan dari tiga posisi: kiri, tengah, dan kanan. Adapun nilai validitas tes $\mathbf{0 . 9 9 5}$ dan nilai reliabilitas tes $\mathbf{0 . 9 9 4}$.

\section{Daftar Pustaka}

Borg, W. R. \& Gall, M. D. (1983). Educational research: an introduction (4th ed.). New York: Longman Inc.

Departemen Pendidikan Nasional. (2003). Undang-undang Nomor 20 Tahun 2003 tentang Sistem Pendidikan Nasional. Jakarta.

Hadi, S. (2004). Metodologi riset. (2nd ed.). Yogyakarta: Penerbit Fakultas Psikologi UGM

IHF. (2012). International handball federation. rules of the game. Basel Switszerland.

FIK UNY (2014). Kurikulum program studi pendidikan jasmani, kesehatan, dan rekreasi 2014, KKNI \& KBK. Yogyakarta: FakultasIlmu Keolahragaan UNY.

Moustafa, H. (2010). Teaching handball at School. introduction to handball for student aged 5 to 11. Handbook. International Handball Federation. (IHF).

Rachman, H. A. \& Susanto, E. (2005). Bolatangan, sebuah pengantar dalam pembelajaran. Universitas Negeri Yogyakarta.

Sugiyono. (2003). Metode penelitian bisnis. Bandung: Alfabeta.

Suntoda, A. (2007). Pedoman dan instrumen praktikum tes dan pengukuran olahraga. Panduan Praktikum. Bandung.

Sukmadinata, N. S. (2004). Kurikulum dan pembelajaran kompetensi. Bandung: Kesuma Karya.

Susanto, E. (2015). Olahraga permainan bola tangan. Yogyakarta: UNY Press.

Thum, Hans-Peter. (2005). Handball elementary course for physical education teachers and students. State University of Yogyakarta.

Thorndike, Robert L. (1982). Applied Psycometrics. Houghton Mifflin Company Boston Massachusetts. 
Trihendardi, Cornelius. (2004). Langkah mudah memecabkan kasus statistik: deskriptif, parametrik dan non-parametrik dengan SPSS 12. Yogyakarta: Andi Offset.
Widhiarso, Wahyu. (2006). Mengestimasi reliabilitas, SPSS untuk psikologi. Yogyakarta: Fakultas Psikologi. 